\title{
Article \\ Effect of Ultrasound-Assisted Solvent Enzymatic Extraction on Fatty Acid Profiles, Physicochemical Properties, Bioactive Compounds, and Antioxidant Activity of Elaeagnus mollis Oil
}

\author{
Xiaorui Lu ${ }^{1}$, Hongmiao $\mathrm{Du}^{2}$, Yuanyuan Liu ${ }^{1}$, Yong Wang ${ }^{3}$, Dong $\mathrm{Li}^{1, *}$ and Lijun Wang ${ }^{4, *}$ \\ 1 Beijing Advanced Innovation Center for Food Nutrition and Human Health, National Energy R \& D Center \\ for Non-Food Biomass, College of Engineering, China Agricultural University, P.O. Box 50, \\ 17 Qinghua Donglu, Beijing 100083, China; luxiaorui118@163.com (X.L.); liu-yy@cau.edu.cn (Y.L.) \\ 2 Beijing Products Quality Supervision and Inspection Institute, 9 Shunxing Road, Beijing 101300, China; \\ duhongmiao@126.com \\ 3 School of Chemical Engineering, UNSW, Sydney, NSW 2052, Australia; Yong.wang2@unsw.edu.au \\ 4 Beijing Key Laboratory of Functional Food from Plant Resources, College of Food Science and Nutritional \\ Engineering, China Agricultural University, 17 Qinghua Donglu, Beijing 100083, China \\ * Correspondence: dongli@cau.edu.cn (D.L.); wlj@cau.edu.cn (L.W.); Tel./Fax: +86-10-62737351 (D.L.)
}

check for updates

Citation: Lu, X.; Du, H.; Liu, Y.; Wang, Y.; Li, D.; Wang, L. Effect of Ultrasound-Assisted Solvent Enzymatic Extraction on Fatty Acid Profiles, Physicochemical Properties, Bioactive Compounds, and Antioxidant Activity of Elaeagnus mollis Oil. Foods 2022, 11, 359 https://doi.org/10.3390/ foods11030359

Received: 8 January 2022

Accepted: 23 January 2022

Published: 26 January 2022

Publisher's Note: MDPI stays neutral with regard to jurisdictional claims in published maps and institutional affiliations.

Copyright: (c) 2022 by the authors. Licensee MDPI, Basel, Switzerland. This article is an open access article distributed under the terms and conditions of the Creative Commons Attribution (CC BY) license (https:// creativecommons.org/licenses/by/ $4.0 /)$.

\begin{abstract}
Elaeagnus mollis oil extracted from the nuts of Elaeagnus mollis Diels can be used in food and pharmaceutical applications due to its excellent nutritional value. An ultrasound-assisted solvent enzymatic extraction (UASEE) method was used to extract oil from Elaeagnus mollis Diels with $n$-hexane solvent $(1: 11.6 \mathrm{~g} / \mathrm{mL})$ and 1.1\% $(w / w)$ mixed enzymes (neutral protease:hemicellulase:pectinase = 1:1:1, $w / w / w)$. The physicochemical properties, fatty acid profile, bioactive compounds, antioxidant activity, morphology, and thermal stability of UASEE oil were investigated and compared with soxhlet extraction (SE) oil and cold pressing (CP) oil. The UASEE oil exhibited a higher content of unsaturated fatty acids $(93.96 \pm 0.28 \%)$, total tocopherols and tocotrienols $(147.32 \pm 2.19 \mathrm{mg} / 100 \mathrm{~g})$, total phytosterols $(261.78 \pm 5.74 \mathrm{mg} / 100 \mathrm{~g})$, squalene $(96.75 \pm 0.31 \mathrm{mg} / 100 \mathrm{~g})$, total phenolic content $(84.76 \pm 2.37 \mathrm{mg} \mathrm{GAE} / \mathrm{kg})$, and antioxidant activity $(12.52 \pm 0.28 \mathrm{mg} / \mathrm{mL})$ than SE and CP oil. The lower peroxide value and acid value in UASEE oil indicated its better quality and lower likelihood of rancidity. The oil obtained using UASEE had higher thermal stability as well, as indicated by thermogravimetric analysis. Scanning electron microscopy (SEM) showed that the UASEE process causes damage to cell walls, and the leakage of substances in the cells facilitates extraction in the following step. Thus, UASEE is a promising processing method for the extraction of Elaeagnus mollis oil.
\end{abstract}

Keywords: ultrasound-assisted solvent enzymatic extraction (UASEE); Elaeagnus mollis oil; physicochemical properties; antioxidant activity; thermal behavior

\section{Introduction}

Currently, health-conscious consumers drive demand for safer and higher-quality products in the global marketplace. In particular, oil extracted from plant species which have medical and health functions is gaining increased attention [1]. Many studies have investigated biological properties of plant oils including their antimicrobial, antifungal, insecticidal, antioxidant, and anticancer uses [2-5]. The extracted plant-based oils are generally used in cooking, cosmetics, health supplement capsules, and other purposes [6].

Elaeagnus mollis (E. mollis) oil is a new commercial product with excellent nutritional value. The oleic and linoleic acid contents in E. mollis oil are over $80 \%$. In addition, E. mollis oil is described as being rich in tocopherols, tocotrienols, squalene, phytosterol, and phenolic content $[7,8]$. E. mollis oil is considered a nutritional food and has attracted the interest of health-conscious consumers because of its pharmacological activities [9-11].

Cold pressing (CP) and solvent extraction (SE) are two conventional and common methods for the extraction of E. mollis oil. $\mathrm{CP}$ is able to better preserve the native attributes 
of oil such as flavor and color, although low oil yields limit its industrial application [12] SE is prevalently used in the food and pharmaceutical industries for its high oil extraction efficiency; however, the high extraction temperature and long extraction time required lead to a loss of bioactive phytochemicals [13]. Therefore, it is essential to explore an effective extraction method for oil in order to improve the efficiency of extraction and preserve the quality attributes of the oil.

Compared with the two conventional extraction technologies, the UASEE process of enzymatic extraction is stimulated by ultrasonic waves which break the cell walls to permit enzyme-aided reactions and the consequent discharge of targeted components [14]. Heidari and Dinani [15] found that using an ultrasonic process combined with enzymatic treatment obtained a higher yield of peanut oil. Ghasemi and Dinani [6] reported this combined treatment could obtain higher oil yields and enhance the release of total phenolic content by disrupting walnut cells. Similarly, Amigh and Dinani [16] applied the combined treatment for promoting oil content in date seeds.

Recent studies of E. mollis oil have focused on optimal extraction conditions [8,17]. Lu, et al. [18] illustrated that ultrasound-assisted enzymatic extraction using an $n$-hexane solvent method for $E$. mollis oil extraction has the advantages of high oil yield and lower consumption of both energy and time. However, there have been no comprehensive studies comparing the quality of E. mollis oil obtained using UASEE and traditional methods. In addition, the comparison of changes to the microstructure of E. mollis seeds between before and after extraction by UASEE has not been previously reported.

The current research study evaluates the fatty acid profile, physicochemical properties, bioactive compounds (tocopherols, tocotrienols, squalene, phytosterol, and phenolic contents), antioxidant activity, and thermal behavior of UASEE oil and compares it with oil obtained using the SE and CP methods. In addition, we observe the differences in the microstructure of $E$. mollis before and after extraction using the UASEE process.

\section{Materials and Methods}

\subsection{Chemicals and Plant Materials}

Fatty acid methyl ester, tocopherols $(\alpha, \beta, \gamma$, and $\delta)$, tocotrienols $(\alpha, \beta, \gamma$, and $\delta)$, phytosterol, squalene, 4-hydroxybenzoic acid, caffeic acid, chlorogenic acid, cinnamic acid, gallic acid, vanillic acid, p-coumaric acid, sinapic acid, ferulic acid, ellagic acid, salicylic acid, vanillin, epicatechin, quercetin and 2,2-diphenyl-1-picrylhydrazyl (DPPH) were obtained from Sigma-Aldrich Chemical Co., Ltd. (Shanghai, China). Folin-Ciocalteu reagent, chromatographic grade methanol, acetonitrile, formic acid and $n$-hexane were purchased from Thermo Scientific (Beijing, China). All reagents and chemicals were kept at analytical grade and were purchased from the Sinopharm Chemical Reagent Beijing Co., Ltd., (Beijing, China).

The E. mollis seeds used in this study were bought from a local market in Yi cheng, Shanxi province, China. The collected seeds were manually de-hulled and air-dried until the moisture content was below 5\%. Then, the kernels were ground with a disintegrator and passed through a 40-mesh sieve to obtain a homogeneous and fine powder, which was stored in polyethylene containers at $4{ }^{\circ} \mathrm{C}$ until analysis.

\subsection{Oil Extraction}

\subsubsection{UASEE}

E. mollis seed oil extraction was carried out according as in our previous paper [18]. The powder was mixed with $n$-hexane $(1: 11.6 \mathrm{~g} / \mathrm{mL})$ at room temperature, followed by ultrasonication at a power of $583 \mathrm{~W}$ using an ultrasonic bath (KH-250DE, Kunshan, China) at $40{ }^{\circ} \mathrm{C}$ for $60 \mathrm{~min}$. Mixed enzymes of $1.1 \% \mathrm{w} / \mathrm{w}$ (neutral protease/hemicellulase/pectinase in equal proportions) were adjusted to $\mathrm{pH} 5.0$ by aqueous sodium hydrogen phosphate $(0.2 \mathrm{M})$ and aqueous citric acid $(0.1 \mathrm{M})$ buffer solution and added to the ultrasonic extracted solutions. Then, the mixtures were incubated in a shaker at a rate of $100 \mathrm{rpm}$ for $2 \mathrm{~h}$ at $50{ }^{\circ} \mathrm{C}$. 
The supernatant was filtered and the solvent was removed by a rotary vacuum evaporator (RV 8, IKA, Staufen, Germany) at $50^{\circ} \mathrm{C}$.

\subsubsection{SE}

A slightly modified soxhlet standard extraction method as described by the Association of Official Analytical Chemists (AOAC) [19] was used. The powder (10 g) was mixed with $n$ hexane $(100 \mathrm{~mL})$ using a soxhlet extractor at $80^{\circ} \mathrm{C}$ for $9 \mathrm{~h}$, followed by $n$-hexane separation using a rotary vacuum evaporator at $50{ }^{\circ} \mathrm{C}$.

\subsection{3. $\mathrm{CP}$}

E. mollis oil was extracted by cold pressing for comparison using a mechanical screw press (ZJ-420, Dongguan, Guangdong, China).

The collected oil was centrifuged at $4{ }^{\circ} \mathrm{C}$ for $5 \mathrm{~min}$ at $9500 \mathrm{rpm}$ and stored at $4{ }^{\circ} \mathrm{C}$ in brown bottles for further analysis.

\subsection{Physicochemical Characteristics}

The specific gravity, refractive index, saponification value, iodine value, peroxide value, and acid value were determined according to the AOAC official methods [19].

\subsection{Fatty Acid Profiles}

Fatty acid profiles were determined using a chromatograph-mass spectrometer (7890N5795C, Agilent Technologies, CA, USA), equipped with a CP-Sil 88 capillary column $(100 \mathrm{~m} \times 0.25 \mathrm{~mm}, 0.20 \mu \mathrm{m}$ film thickness, Agilent Technologies, CA, USA). Prior to analysis, the oil was transformed into fatty acid methyl esters (FAMEs) according to the method reported by Naik, et al. [20]. Both the injector and the detector temperatures were maintained at $250{ }^{\circ} \mathrm{C}$. The oven temperature was programmed isothermally to $140{ }^{\circ} \mathrm{C}$ for $5 \mathrm{~min}$ and then heated to $210{ }^{\circ} \mathrm{C}\left(4^{\circ} \mathrm{C} / \mathrm{min}\right)$ for $5 \mathrm{~min}$. The injected volume was $1.0 \mu \mathrm{L}$ and the split rate was 1:20. The fatty acid profiles were identified according to their chromatographic and mass spectral characteristics (GC-MS databases, NIST.11) and retention time.

\subsection{Bioactive Compounds}

2.5.1. Tocopherols and Tocotrienols

For quantification of tocopherols and tocotrienols, the oil was saponified, then the compounds were determined by the HPLC method as described by Ben Mohamed et al. [21] with minor changes. The contents of tocopherols and tocotrienols were measured by an LC-20A high-performance liquid chromatography (Shimadzu, Kyoto, Japan) using a C30 column (4.6 mm $\times 250 \mathrm{~mm}, 5 \mu \mathrm{m}$, Shimadzu, Kyoto, Japan) and an RF-20A xs fluorescence detector (Shimadzu, Kyoto, Japan).

\subsubsection{Squalene}

For analysis of squalene, oil samples were prepared based on the official method NY/T 3673-2020 of the Ministry of Agriculture of China, with slight modifications [22]. using a chromatograph-mass spectrometer (GC-QP2010, Shimadzu, Kyoto, Japan) equipped with an RTX-5MS capillary column $(30 \mathrm{~m} \times 0.25 \mathrm{~mm}, 0.25 \mu \mathrm{m}$ film thickness, Shimadzu, Kyoto, Japan). The column temperature was set at $200{ }^{\circ} \mathrm{C}$ and held for $1 \mathrm{~min}$; then, the temperature was raised at a rate of $25^{\circ} \mathrm{C} / \mathrm{min}$ and maintained at $300{ }^{\circ} \mathrm{C}$ for $5 \mathrm{~min}$. The source temperature was $230^{\circ} \mathrm{C}$, the split rate was $1 / 50$, and the injection volume was $1.0 \mu \mathrm{L}$. Squalene was identified and calculated using the external standard to create a calibration curve.

\subsubsection{Phytosterols}

Phytosterols were measured using LC-MS/MS according to the National Recommended Standard GB/T 39995-2021 of China, with minor modifications [23]. Phytosterols were separated on a C18 column (shim-pack GIST, $100 \mathrm{~mm} \times 2.1 \mathrm{~mm} \times 2 \mu \mathrm{m}$, Shimadzu, 
Kyoto, Japan) using a Shimadzu LCMS-8050 system equipped with an atmospheric pressure chemical ionization (APCI) source for the mass spectrometer (Shimadzu, Kyoto, Japan). Acetonitrile was used as phase $\mathrm{A}$ and water $(0.1 \%$ formic acid) was used as phase B. The eluent gradient was programmed as follows: $80-100 \%$ A (0-2.5 min), 100\% A (2.5-9 min), $100-80 \%$ A (9-9.1 $\mathrm{min})$, and $80 \%$ A (9.1-15 $\mathrm{min})$. The injection volume was $2 \mu \mathrm{L}$, with a $0.4 \mathrm{~mL} / \mathrm{min}$ flow rate.

The APCI source of the mass spectrometer operated at a capillary voltage of $4.0 \mathrm{kV}$ in the positive ion mode with the source temperature set at $300^{\circ} \mathrm{C}$ and a desolvation gas flow of $10 \mathrm{~L} / \mathrm{min}$ and desolvation temperature of $400{ }^{\circ} \mathrm{C}$. Quantification of phytosterols was carried out using 6-Ketocholestanol as an internal standard.

\subsubsection{Total Phenolic Content (TPC)}

Analysis of the total phenolic content (TPC) of E. mollis oil was determined as reported by Lee, et al. [12] using Folin-Ciocalteau method, with slight modifications. Briefly, the oil sample $(0.2 \mathrm{~g})$ was mixed with $2.5 \mathrm{~mL}$ methanol and $0.5 \mathrm{~mL}$ Folin-Ciocalteu reagent and shaken. Next, $1 \mathrm{~mL} \mathrm{Na} \mathrm{CO}_{3}$ solution $(75 \mathrm{~g} / \mathrm{L})$ was added to the mixture and the final volume was brought up to $10 \mathrm{~mL}$ with deionized water. The test was held in a dark place at room temperature for $2 \mathrm{~h}$, then absorbance was read at $765 \mathrm{~nm}$ using a UV-2550 spectrophotometer (Shimadzu, Kyoto, Japan). Gallic acid was taken as the standard and the values were expressed as mg Gallic acid equivalents (GAE) per $\mathrm{kg}$ of sample oil (mg GAE/kg oil).

\subsubsection{Phenolic Compounds}

For analysis of phenolic compounds, the oil sample $(1.0 \mathrm{~g})$ was dissolved in $n$-hexane $(5 \mathrm{~mL})$, then phenolic compounds were fractionated based on a modified method by Ribeiro, et al. [24] using weak cation exchange (WCX) solid-phase extraction cartridges. Ultra-high performance liquid chromatography with mass spectrometry (LCMS-8050, Shimadzu, Tokyo, Japan) was performed to identify and quantify individual phenolic compounds, and a C18 column (shim-pack GIST, $100 \mathrm{~mm} \times 2.1 \mathrm{~mm} \times 2 \mu \mathrm{m}$, Shimadzu, Kyoto, Japan) was used. Acetonitrile and formic acid $(0.1 \%)$ were used as mobile phases A and B, with a flow rate of $0.3 \mathrm{~mL} / \mathrm{min}$. The gradient elution program comprised $10-95 \% \mathrm{~A}(0-3.5 \mathrm{~min}), 95 \% \mathrm{~A}$ (3.5-3.9 $\mathrm{min}), 95-10 \%$ A (3.9-4 $\mathrm{min}), 10 \%$ A (4-6 min).The capillary voltage was $4.0 \mathrm{kV}$, the desolvation gas flow $10 \mathrm{~L} / \mathrm{min}$, the source temperature $300{ }^{\circ} \mathrm{C}$, and the desolvation temperature $400^{\circ} \mathrm{C}$. Electrospray ionization (ESI) (negative-ion mode) and multiple reaction monitoring (MRM) mode were used for quantitative analysis. Appropriate phenolic standards (4-hydroxybenzoic acid, caffeic acid, chlorogenic acid, cinnamic acid, gallic acid, vanillic acid, p-coumaric acid, sinapic acid, ferulic acid, ellagic acid, salicylic acid, vanillin, epicatechin, quercetin) were used for comparison and quantification; information about the quantification of the phenolic compounds (regression equations, $R^{2}$, Linear range, quantitative ion, LOD, LOQ) is shown in Table 1 and Figure S1.

\subsection{Antioxidant Activity}

The antioxidant activity of E. mollis oil was evaluated based on DPPH radical scavenging activity according to the previous method reported by Kan, et al. [17]. E. mollis oil was dissolved in ethanol (concentrations of 2, 4, 8, 12, 16, 20, and $24 \mathrm{mg} / \mathrm{mL}$ ). Two milliliters of sample solution were mixed with the same volume of DPPH $\left(2 \times 10^{-4} \mathrm{~mol} / \mathrm{L}\right)$ ethanol solution. Then, the mixtures were shaken and kept in a dark place at room temperature for $30 \mathrm{~min}$. The absorbance readings were recorded at $517 \mathrm{~nm}$ using a spectrophotometer (UV-2550, Shimadzu, Kyoto, Japan).

$$
\text { DPPH radical scavenging activity }(\%)=\left(\frac{A_{0}-A_{1}}{A_{0}}\right) \times 100
$$

In this equation, $A_{0}$ is the absorbance of the control group and $A_{1}$ is the absorbance of the sample group. 
Table 1. The quantification information of phenolics in E. mollis oil.

\begin{tabular}{|c|c|c|c|c|c|c|c|c|}
\hline No. & Compounds & Regression Equation & $\mathbf{R}^{2}$ & $\begin{array}{l}\text { Linear } \\
\text { Range } \\
\text { ( } \mu \mathrm{g} / \mathrm{L})\end{array}$ & $m / z$ & $\begin{array}{c}\text { RT } \\
(\mathrm{min})\end{array}$ & $\begin{array}{l}\text { LOD } \\
(\mathrm{mg} / \mathrm{kg})\end{array}$ & $\begin{array}{c}\mathrm{LOQ} \\
(\mathrm{mg} / \mathrm{kg})\end{array}$ \\
\hline 1 & chlorogenic acid & $Y=13025.5 X+9211.17$ & 0.9999 & $2-500$ & $353.1 / 191.1$ & 1.597 & 1.5 & 5.0 \\
\hline 2 & cinnamic acid & $Y=1833.16 X+5305.62$ & 0.9987 & $2-500$ & $149.0 / 131.0$ & 2.263 & 1.5 & 5.0 \\
\hline 3 & gallic acid & $Y=422.457 X+142.217$ & 0.9998 & $2-200$ & $169.0 / 79.1$ & 2.360 & 0.15 & 0.5 \\
\hline 4 & vanillic acid & $Y=150.973 X+1120.40$ & 0.9973 & $2-200$ & $167.1 / 108.0$ & 2.588 & 0.3 & 1.0 \\
\hline 5 & $\mathrm{p}$-coumaric acid & $Y=9272.58 X+12986.6$ & 0.9999 & $2-200$ & $163.0 / 119.1$ & 2.555 & 0.3 & 1.0 \\
\hline 6 & sinapic acid & $Y=1819.15 X-4545.19$ & 0.9990 & $2-500$ & $223.1 / 164.1$ & 2.655 & 1.5 & 5.0 \\
\hline 7 & ferulic acid & $Y=2826.58 X-229.223$ & 0.9999 & $2-200$ & $193.1 / 134.1$ & 2.871 & 0.3 & 1.0 \\
\hline 8 & ellagic acid & $Y=175.979 X-1233.08$ & 0.9990 & $2-200$ & $301.2 / 229.0$ & 2.913 & 0.3 & 1.0 \\
\hline 9 & salicylic acid & $Y=18774.9 X+97389.3$ & 0.9999 & $2-200$ & 137.1/93.1 & 2.943 & 0.3 & 1.0 \\
\hline 10 & 4-hydroxybenzoic acid & $Y=8625.58 X+27775.2$ & 0.9997 & $2-200$ & $137.1 / 93.1$ & 2.973 & 0.15 & 0.5 \\
\hline 11 & vanillin & $Y=11935.6 X+31234.6$ & 0.9999 & $2-200$ & $153.2 / 93.2$ & 3.305 & 0.3 & 1.0 \\
\hline 12 & epicatechin & $Y=1594.97 X-4848.19$ & 0.9983 & $2-800$ & $305.1 / 125.0$ & 3.307 & 5.0 & 20.0 \\
\hline 13 & quercetin & $Y=4288.29 X-7960.59$ & 0.9996 & $2-200$ & $301.0 / 151.0$ & 3.309 & 0.15 & 0.5 \\
\hline 14 & caffeic acid & $Y=9052.98 X+16558.7$ & 0.9999 & $2-200$ & $179.1 / 135.1$ & 3.519 & 0.3 & 1.0 \\
\hline
\end{tabular}

\subsection{Scanning Electron Micrographs (SEM)}

Scanning electron micrographs (SEM) were used to reveal the microstructure of the raw materials according to the method of Liu, et al. [25] with slight modifications. The SEM images of surface morphological changes of unextracted and extracted seed powders were taken using a scanning electron microscope, FEI-Quanta 450 (Thermo Fisher Scientific, Waltham, MA, USA).

\subsection{Thermal Stability}

The thermal stability analysis of E. mollis oil was performed using a TGA 5500 (TA Instrument, DE, USA). A heating rate of $10{ }^{\circ} \mathrm{C} / \mathrm{min}$ with a temperature in the range of 25-600 ${ }^{\circ} \mathrm{C}$ was used to carry out this analysis [26].

\subsection{Statistical Analysis}

All experiments were carried out in triplicate, and the results are presented as the mean value \pm standard deviation. Statistical analysis was performed using Minitab 17 (Minitab Inc., Chicago, IL, USA) followed by Tukey's test $(p<0.05)$.

\section{Results and Discussion}

\subsection{Fatty Acid Profiles}

Through chromatography-mass spectrometry twelve fatty acid components were identified, including seven saturated fatty acids (SFA), two monounsaturated fatty acids (MUFA) and three polyunsaturated fatty acids (PUFA) (Table 2). The primary fatty acids in E. mollis oil were linoleic acid (46.4 53.1\%) and oleic acid (33.5 38.9\%), which are considered to have high nutritional values thanks to their preventative effects against cardiovascular disease and cancer [27]. As seen in Table 2, the three oil products obtained from different extraction methods were rich in unsaturated fatty acids (90.9 93.96\%) and the higher content of unsaturated fatty acids resulted from the UASEE process, which could cause a higher iodine value. Similar results were reported for the ultrasonic-enzymatic extraction of walnut oil [6]. Additionally, it was found that the most significant difference between three E. mollis oil products from different methods of extraction (UASEE, SE, and $\mathrm{CP}$ ) was in the content rather than the components of fatty acids. The linoleic acid and polyunsaturated fatty acid content of the E. mollis oil obtained by the UASEE process (53.1\% and 59.78\%) was higher than that obtained by the SE (48.4\% and 55.3\%) and CP (46.4\% and 53.62\%) methods. Li, et al. [28] proposed that more polyunsaturated fatty acids in the dietary fats could prevent coronary heart and high blood pressure diseases. The reason for the higher content could be the relatively low extraction temperature and short extraction time of UASEE, which might help to prevent the oxidation and decomposition of unsaturated fatty acids [29]. 
Table 2. Fatty acid profiles of E.mollis oil extracted by three methods.

\begin{tabular}{cccc}
\hline \multirow{2}{*}{ Fatty Acid Profiles (\%) } & \multicolumn{3}{c}{ Extraction Methods } \\
\cline { 2 - 4 } & UASEE & SE & CP \\
\hline Myristic (14:0) & $0.02 \pm 0.00^{\mathrm{a}}$ & $0.02 \pm 0.00^{\mathrm{a}}$ & $0.02 \pm 0.00^{\mathrm{a}}$ \\
Pentadecanoic (15:0) & $0.02 \pm 0.00^{\mathrm{a}}$ & $0.02 \pm 0.00^{\mathrm{a}}$ & $0.02 \pm 0.00^{\mathrm{a}}$ \\
Palmitic acid (16:0) & $3.42 \pm 0.13^{\mathrm{c}}$ & $5.72 \pm 0.26^{\mathrm{a}}$ & $4.03 \pm 0.13^{\mathrm{b}}$ \\
Margaric (17:0) & $0.05 \pm 0.00^{\mathrm{a}}$ & $0.05 \pm 0.00^{\mathrm{a}}$ & $0.05 \pm 0.00^{\mathrm{a}}$ \\
Stearic acid (18:0) & $2.15 \pm 0.15^{\mathrm{b}}$ & $2.91 \pm 0.14^{\mathrm{a}}$ & $2.42 \pm 0.20^{\mathrm{b}}$ \\
Arachidic acid (20:0) & $0.32 \pm 0.01^{\mathrm{a}}$ & $0.35 \pm 0.02^{\mathrm{a}}$ & $0.21 \pm 0.01^{\mathrm{b}}$ \\
Behenic (22:0) & $0.06 \pm 0.00^{\mathrm{a}}$ & $0.06 \pm 0.00^{\mathrm{a}}$ & $0.06 \pm 0.00^{\mathrm{a}}$ \\
Saturated fatty acids (SFA) & $6.04 \pm 0.29^{\mathrm{c}}$ & $9.13 \pm 0.41^{\mathrm{a}}$ & $6.81 \pm 0.15^{\mathrm{b}}$ \\
\hline Oleic acid (18:1) & $33.5 \pm 0.21^{\mathrm{c}}$ & $34.9 \pm 0.20^{\mathrm{b}}$ & $38.9 \pm 0.15^{\mathrm{a}}$ \\
Eicosenoic acid (20:1) & $0.64 \pm 0.01^{\mathrm{b}}$ & $0.70 \pm 0.01^{\mathrm{a}}$ & $0.64 \pm 0.03^{\mathrm{b}}$ \\
Monounsaturated fatty acids (MUFA) & $34.18 \pm 0.21^{\mathrm{c}}$ & $35.60 \pm 0.21^{\mathrm{b}}$ & $39.57 \pm 0.18^{\mathrm{a}}$ \\
\hline Eicosadienoic (20:2) & $0.10 \pm 0.00^{\mathrm{a}}$ & $0.10 \pm 0.01^{\mathrm{a}}$ & $0.10 \pm 0.01^{\mathrm{a}}$ \\
Linoleic acid (18:2) & $53.1 \pm 0.35^{\mathrm{a}}$ & $48.4 \pm 0.67^{\mathrm{b}}$ & $46.4 \pm 0.38^{\mathrm{c}}$ \\
$\alpha$-linolenic acid (18:3) & $6.55 \pm 0.12^{\mathrm{b}}$ & $6.84 \pm 0.27^{\mathrm{b}}$ & $7.09 \pm 0.13^{\mathrm{a}}$ \\
Polyunsaturated fatty acids (PUFA) & $59.78 \pm 0.44^{\mathrm{a}}$ & $55.30 \pm 0.60^{\mathrm{b}}$ & $53.62 \pm 0.24^{\mathrm{b}}$ \\
\hline Unsaturated fatty acids (UFA) & $93.96 \pm 0.28^{\mathrm{a}}$ & $90.9 \pm 0.35^{\mathrm{b}}$ & $93.19 \pm 0.19^{\mathrm{b}}$ \\
\hline Values are means \pm SD $(n=3)$. Different letters within a row represent significant difference at $p<0.05$.
\end{tabular}

\subsection{Physicochemical Properties}

Table 3 illustrates the physicochemical properties of oils obtained from different methods. The acid value was used to measure the acidity of the oil, and the peroxide value was used to measure the oxidation state of lipids [30,31]. Acid value and peroxide value determine the oxidation and rancidity of vegetable oil. As seen in Table 3, the UASEE oil product showed a significantly lower peroxide value $(0.14 \pm 0.01 \mathrm{~g} / 100 \mathrm{~g})$ and acid value $(1.91 \pm 0.02 \mathrm{mg} / \mathrm{g})$ compared to SE oil $(0.21 \pm 0.03 \mathrm{~g} / 100 \mathrm{~g}$ and $2.47 \pm 0.04 \mathrm{mg} / \mathrm{g})$, indicating that the oil obtained with the UASEE method exhibited a better quality with less rancidity [30]. Additionally, according to Ma, et al. [32], the lower acid value of UASEE oil could be the result of the neutralization of free fatty acids by the alkaline extraction environment during the extraction process, while the high temperature and prolonged extraction period during the SE process could be expected to accelerate the oxidative rancidity of oil [33].

Table 3. Oil yield and physicochemical properties of E.mollis oil extracted by three methods.

\begin{tabular}{cccc}
\hline \multirow{2}{*}{ Physicochemical Properties } & \multicolumn{3}{c}{ Extraction Methods } \\
\cline { 2 - 4 } & UASEE & SE & CP \\
\hline Oil yield $(\%)$ & $43.35 \pm 0.26^{\mathrm{a}}$ & $43.02 \pm 0.77^{\mathrm{a}}$ & $22.05 \pm 0.12^{\mathrm{b}}$ \\
Specific gravity $\left(20^{\circ} \mathrm{C} / \mathrm{g} / \mathrm{mL}\right)$ & $0.9150 \pm 0.00^{\mathrm{a}}$ & $0.9149 \pm 0.00^{\mathrm{a}}$ & $0.9149 \pm 0.00^{\mathrm{a}}$ \\
Refractive index $\left(20^{\circ} \mathrm{C}\right)$ & $1.474 \pm 0.00^{\mathrm{a}}$ & $1.474 \pm 0.00^{\mathrm{a}}$ & $1.474 \pm 0.00^{\mathrm{a}}$ \\
Acid value $(\mathrm{mg} / \mathrm{g})$ & $1.91 \pm 0.02^{\mathrm{a}}$ & $2.47 \pm 0.04^{\mathrm{b}}$ & $1.87 \pm 0.03^{\mathrm{a}}$ \\
Peroxide value $(\mathrm{g} / 100 \mathrm{~g})$ & $0.14 \pm 0.01^{\mathrm{a}}$ & $0.21 \pm 0.03^{\mathrm{b}}$ & $0.12 \pm 0.02^{\mathrm{a}}$ \\
Iodine value $(\mathrm{g} / 100 \mathrm{~g})$ & $162.96 \pm 2.35^{\mathrm{a}}$ & $151.35 \pm 1.96^{\mathrm{b}}$ & $160.31 \pm 1.87^{\mathrm{a}}$ \\
Saponification value $(\mathrm{mg} / \mathrm{g})$ & $174.47 \pm 2.60^{\mathrm{a}}$ & $174.48 \pm 2.13^{\mathrm{a}}$ & $176.77 \pm 1.49^{\mathrm{a}}$ \\
\hline
\end{tabular}

Values are means $\pm \mathrm{SD}(n=3)$. Different letters within a row represent a significant difference at $p<0.05$.

The iodine value of the UASEE oil $(162.96 \pm 2.35 \mathrm{~g} / 100 \mathrm{~g})$ was slightly higher than that of the SE $(151.35 \pm 1.96 \mathrm{~g} / 100 \mathrm{~g})$ and CP $(160.31 \pm 1.87 \mathrm{~g} / 100 \mathrm{~g})$ oils (Table 3). Previous studies of the extraction of samara oil [34], walnut kernel oil [6], and Sapindus mukorossi seed kernel oil [35] all reported that the oil extracted by ultrasonic processes exhibited a higher iodine value and more unsaturated fatty acids than the SE products. These results are in good agreement with ours in the present study. There were no significant differences 
in the specific gravity, refractive index, and saponification values with the three methods, indicating that the purity and average molecular weight of fatty acids were similar [36]. Therefore, in terms of fatty acid profiles and physicochemical properties, UASEE served as the better alternative for the extraction of E. mollis oil.

\subsection{Bioactive Compounds}

\subsubsection{Tocopherols and Tocotrienols}

Table 4 and Supplementary Figures S1 and S2 illustrates the tocopherol and tocotrienol profiles and contents in oils obtained with the different methods. In this study, levels of total tocopherols and tocotrienols are expressed as the sum of $\alpha$-tocopherol, $\gamma$-tocopherol, $\delta$-tocopherol, $\alpha$-tocotrienol, $\gamma$-tocotrienol, and $\delta$-tocotrienol. The total tocopherol and tocotrienol contents in E. mollis oil ranged from 123.45 to $147.32 \mathrm{mg} / 100 \mathrm{~g}$, similar to the results of Liang, et al. [37] (119.6-128.6 mg/100 g), although different from those of Wang, Duan, Fan and Li [8] (86.12-96.24 mg/100 g). This might be due to differences in geographical origin, cultivars, and analysis methods.

Table 4. Bioactive compounds and antioxidant activity of E.mollis oil extracted by three methods.

\begin{tabular}{|c|c|c|c|}
\hline \multirow{2}{*}{ Bioactive Compounds } & \multicolumn{3}{|c|}{ Extraction Methods } \\
\hline & UASEE & SE & $\mathrm{CP}$ \\
\hline$\alpha$-tocopherol (mg/100 g) & $3.58 \pm 0.26^{\mathrm{a}}$ & $2.70 \pm 0.15^{b}$ & $3.34 \pm 0.23^{a}$ \\
\hline$\beta$-tocopherol (mg/100 g) & ND & ND & ND \\
\hline$\gamma$-tocopherol (mg/100 g) & $134.50 \pm 2.62^{\mathrm{a}}$ & $111.75 \pm 1.86^{\mathrm{b}}$ & $132.08 \pm 2.39^{\mathrm{a}}$ \\
\hline$\delta$-tocopherol (mg/100 g) & $1.67 \pm 0.05^{\mathrm{a}}$ & $1.71 \pm 0.02^{\mathrm{b}}$ & $1.69 \pm 0.04^{\mathrm{a}}$ \\
\hline$\alpha$-tocotrienol (mg/100 g) & $1.13 \pm 0.11^{\mathrm{b}}$ & $1.53 \pm 0.14^{\mathrm{a}}$ & $1.52 \pm 0.06^{\mathrm{a}}$ \\
\hline$\beta$-tocotrienol (mg/100 g) & ND & ND & ND \\
\hline$\gamma$-tocotrienol (mg/100 g) & $5.72 \pm 0.21^{\mathrm{a}}$ & $4.97 \pm 0.16^{\mathrm{b}}$ & $5.42 \pm 0.12^{\mathrm{a}}$ \\
\hline$\delta$-tocotrienol (mg/100 g) & $0.71 \pm 0.07^{\mathrm{a}}$ & $0.79 \pm 0.05^{\mathrm{a}}$ & $0.80 \pm 0.04^{\mathrm{a}}$ \\
\hline Total tocopherol and tocotrienol (mg/100 g) & $147.32 \pm 2.19^{a}$ & $123.45 \pm 1.74^{b}$ & $144.84 \pm 2.24^{\mathrm{a}}$ \\
\hline$\beta$-Sitosterol (mg/100 g) & $183.13 \pm 4.62^{\mathrm{a}}$ & $170.23 \pm 5.18^{b}$ & $139.03 \pm 4.29^{\mathrm{c}}$ \\
\hline Stigmasterol (mg/100 g) & $6.53 \pm 0.26^{b}$ & $6.72 \pm 0.42^{b}$ & $7.58 \pm 0.24^{\mathrm{a}}$ \\
\hline Ergosterol (mg/100 g) & $20.64 \pm 1.26^{\mathrm{a}}$ & $20.35 \pm 1.19^{a}$ & $16.18 \pm 0.83^{b}$ \\
\hline Lupeol (mg/100 g) & $42.25 \pm 1.37^{\mathrm{a}}$ & $41.17 \pm 0.68^{\mathrm{a}}$ & $35.78 \pm 1.94^{b}$ \\
\hline Stigmastanol (mg/100 g) & $9.24 \pm 0.20^{\mathrm{a}}$ & $9.36 \pm 0.36^{\mathrm{a}}$ & $9.09 \pm 0.17^{\mathrm{a}}$ \\
\hline Total Phytosterol (mg/100 g) & $261.78 \pm 5.74^{\mathrm{a}}$ & $247.82 \pm 4.38^{b}$ & $207.66 \pm 5.24^{c}$ \\
\hline Salicylic acid (mg/kg) & $0.97 \pm 0.03^{\mathrm{a}}$ & $0.79 \pm 0.01^{\mathrm{c}}$ & $0.86 \pm 0.03^{b}$ \\
\hline Ferulic acid (mg/kg) & $2.53 \pm 0.16^{\mathrm{a}}$ & $1.43 \pm 0.10^{\mathrm{c}}$ & $2.09 \pm 0.12^{b}$ \\
\hline Cinnamic acid (mg/kg) & $0.66 \pm 0.03^{\mathrm{a}}$ & $0.63 \pm 0.01^{\mathrm{a}}$ & $0.65 \pm 0.02^{\mathrm{a}}$ \\
\hline $\mathrm{p}$-Coumaric acid (mg/kg) & $1.27 \pm 0.06^{\mathrm{a}}$ & $0.91 \pm 0.07^{\mathrm{c}}$ & $1.09 \pm 0.03^{b}$ \\
\hline DPPH (IC 50) (mg/mL) & $12.52 \pm 0.28^{a}$ & $14.87 \pm 0.48^{b}$ & $13.29 \pm 0.30^{\mathrm{a}}$ \\
\hline
\end{tabular}

ND: not detected. Values are means \pm SD $(n=3)$. Different letters within a row represent a significant difference at $p<0.05$.

The contents of the total tocopherols and tocotrienols of E. mollis oil obtained using the UASEE method $(147.32 \pm 2.19 \mathrm{mg} / 100 \mathrm{~g})$ were the highest of the three methods. It could be concluded that the total tocopherol and tocotrienol contents obtained depended on the extraction method. In the UASEE process, the interactivity between the tocopherols and tocotrienols and the protein was reduced by the enzymes, enhancing the release of tocopherols and tocotrienols into the oil $[33,38,39]$. The results showed that $\gamma$-tocopherol was the main component of E. mollis oil (111.75-134.50 mg/100 g), accounting for a proportion of more than $90 \%$. The $\gamma$-tocopherol content showed a significant difference between UASEE (134.50 $\pm 2.62 \mathrm{mg} / 100 \mathrm{~g})$ and SE $(111.75 \pm 1.86 \mathrm{mg} / 100 \mathrm{~g})$. Mathur, et al. [40] reported that $\gamma$-tocopherol exerted a higher antioxidant capacity, anti-inflammatory, and cardioprotective effect than $\alpha$-tocopherol. Therefore, UASEE seed oil is an ideal dietary source, with more antioxidants. 


\subsubsection{Squalene}

The squalene content of the oils is exhibited in Figure 1; the squalene content showed significant differences between the different extraction methods $(p<0.05)$. The highest squalene content was observed for UASEE oil $(96.75 \pm 0.31 \mathrm{mg} / 100 \mathrm{~g})$, while the lowest was observed for SE oil $(90.58 \pm 0.74 \mathrm{mg} / 100 \mathrm{~g})$. This illustrates that UASEE promotes the release of squalene. The chromatograms of squalene is showed in Supplementary Figures S3 and S4. The squalene content in this study was much higher compared with that of supercritical $\mathrm{CO}_{2}$ extraction $(68.06 \mathrm{mg} / 100 \mathrm{~g})$ [7]. This shows that different extraction methods have an impact on the content of squalene in seed oils.

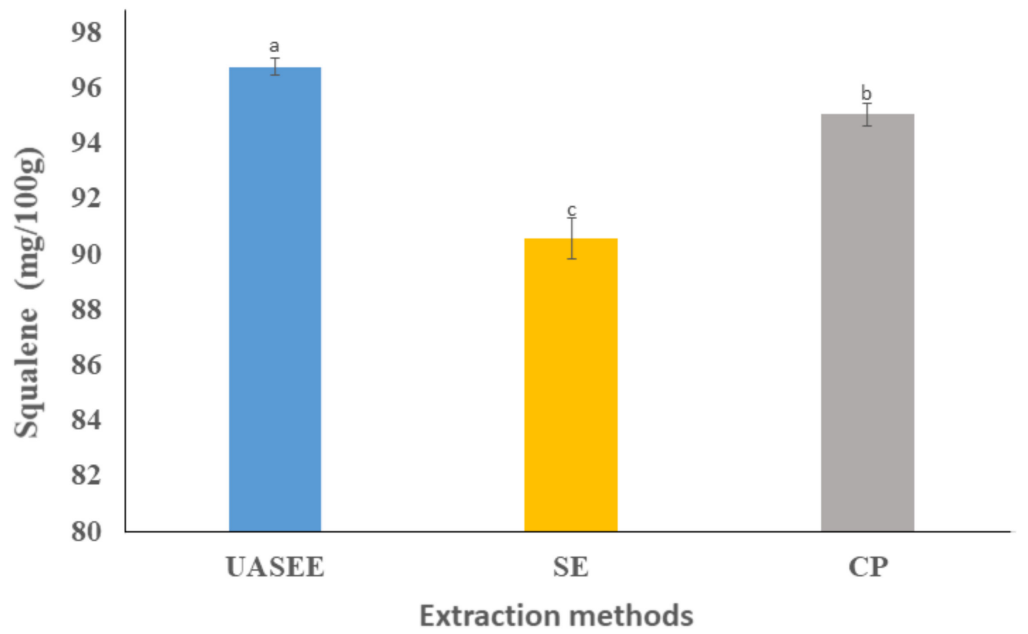

Figure 1. Squalene content of E. mollis oil obtained by different extraction methods. Different letters represent a significant difference at $p<0.05$.

\subsubsection{Phytosterols}

As shown in Table 4, the contents of the individual phytosterols in E. mollis oil were significantly different due to the processing methods $(p<0.05)$. The major phytosterol in E. mollis oil (Supplementary Figures S5-S7) was $\beta$-Sitosterol (from $139.03 \pm 4.29$ to $183.13 \pm 4.62 \mathrm{mg} / 100 \mathrm{~g}$ ), followed by Lupeol (from $35.78 \pm 1.94$ to $42.25 \pm 1.37 \mathrm{mg} / 100 \mathrm{~g}$ ), ergosterol (from $16.18 \pm 0.83$ to $20.64 \pm 1.26 \mathrm{mg} / 100 \mathrm{~g}$ ), stigmastanol (from $9.09 \pm 0.17$ to $9.36 \pm 0.36 \mathrm{mg} / 100 \mathrm{~g}$ ), and stigmasterol (from $6.53 \pm 0.26$ to $7.58 \pm 0.24 \mathrm{mg} / 100 \mathrm{~g}$ ). The total phytosterol content in E. mollis oil obtained by UASEE $(261.78 \pm 5.74 \mathrm{mg} / 100 \mathrm{~g})$ was significantly $(p<0.05)$ higher compared with CP $(207.66 \pm 5.24 \mathrm{mg} / 100 \mathrm{~g})$ and SE $(247.82 \pm 4.38 \mathrm{mg} / 100 \mathrm{~g})$. This is consistent with the results reported by Konopka, et al. [41], who found that the ultrasound-solvent extraction oil and enzyme-extracted oil exhibited higher sterol contents due to the disruption of cell walls caused by enzymatic and ultrasonic treatment. Similarly, according to Fang, et al. [42], this combined treatment can reduce the interaction of phytosterols with the seed proteins, promoting their release into the oil.

\subsubsection{Total Phenolic Content and Profile Analysis}

The total phenolic content (TPC) in E. mollis oil obtained by UASEE $(84.76 \pm 2.37 \mathrm{mg}$ $\mathrm{GAE} / \mathrm{kg})$ was significantly higher compared to that obtained by SE $(67.72 \pm 2.04 \mathrm{mg}$ $\mathrm{GAE} / \mathrm{Kg})$ and $\mathrm{CP}(78.90 \pm 1.57 \mathrm{mg} \mathrm{GAE} / \mathrm{kg})$ (Figure 2). The observed difference may be due to the SE process requiring prolonged extraction times and high temperature, resulting in a reduction in TPC [43].

These results were further confirmed by the quantification of the phenolic compounds in three oils by HPLC-MS (Table 4 and Supplementary Figures S8-S10). In this study, four phenolic compounds were detected in E. mollis oil; ferulic acid was identified as the predominant phenolic compound (from $1.43 \pm 0.10$ to $2.53 \pm 0.16 \mathrm{mg} / \mathrm{kg}$ ), followed by p-coumaric acid, salicylic acid, and cinnamic acid. These phenolic compounds positively influence oil quality, oxidative stability, and shelf life, in addition to health benefits when 
consumed $[24,44]$. The phenolic components have several bioactive and pharmacological properties, including anti-inflammatory activity, and can help to prevent atherosclerosis and cancer [45].

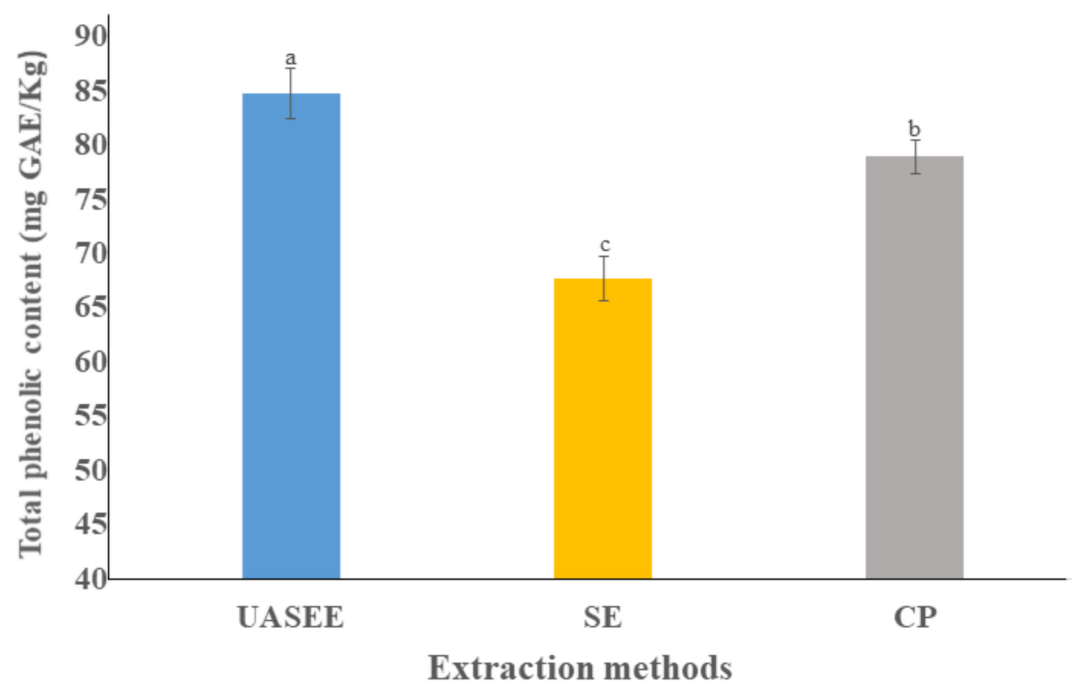

Figure 2. Total phenolic content of E. mollis oil obtained by different extraction methods. Different letters represent a significant difference at $p<0.05$.

As illustrated in Table 4, the UASEE oil presented significantly higher contents of all four phenolic compounds than oil from the other two extraction methods. One explanation for these observed differences in the contents of phenolic compounds may be that certain phenolic compounds might be more easily transferred to oil during the UASEE method. Similarly, Ghasemi and Dinani [6] demonstrated that ultrasonic-enzymatic extraction treatment using $n$-hexane was an effective way to extract walnut oil with higher levels of total phenolic content and iodine value than could be obtained with SE.

\subsection{Antioxidant Activity}

The antioxidant activity of oil extracted by UASEE, SE, and CP was evaluated by DPPH radical scavenging assay. As shown in Figure 3, E. mollis oil's antioxidant activity was dose-dependent within the experimental concentration range. With the increase in the concentration of E. mollis oil, the antioxidant capacity increased. The $\mathrm{IC}_{50}$ (halfmaximal effective concentration) of the oil extracted by UASEE showed significant stronger antioxidant capacity $(12.52 \pm 0.28 \mathrm{mg} / \mathrm{mL})$ compared with the SE $(14.87 \pm 0.48 \mathrm{mg} / \mathrm{mL})$ and CP $(13.29 \pm 0.30 \mathrm{mg} / \mathrm{mL})$ methods. This indicates that E. mollis oil had a strong scavenging activity on DPPH assay, and the highest antioxidant activity was observed for the UASEE method. The DPPH radical scavenging mechanism may occur through the E. mollis oil donating electrons or hydrogen atoms to DPPH [46]. The differences in E. mollis oil products in their bioactive compounds such as PUFA, phenolic compounds and unsaturated fatty acids affect their hydrogen-donating abilities [47]. In the present study, the excellent DPPH radical scavenging ability shown by E. mollis oil produced by UASEE process compared to the SE and CP processes may be the result of its higher content of bioactive compounds and its strong hydrogen-donating ability.

\subsection{Microstructural Analysis}

Figure 4A shows scanning electron microscopy images of E. mollis seed before extraction, exhibiting a compact structure and no destruction of the surface of the cell walls. After SE, a loosened structure with thick porosity was found (Figure 4C). The CP-treated seed had a relatively loose external structure intact (Figure 4D). After extraction by UASEE (Figure 4B) the seed became porous, and most cells were curled, disorganized, and disrupted due to the loss of oil. Rosenthal, et al. [48] reported that the enzymatic treatment 
effectively destructed the cell walls and enhanced the oil released to the solvent. In addition, Zhang, et al. [49] and Jadhav, et al. [50] showed that the collapse of the cavities (bubbles) produced by ultrasonic pretreatment leads to a forceful shockwave and high-speed jet, which results in the creation of crevices, cracks, and micro-fractures. Therefore, the SEM images demonstrate that the enzymatic and ultrasonic treatment resulting in structural rupture of E. mollis seeds was helpful in releasing the oil from the raw materials.

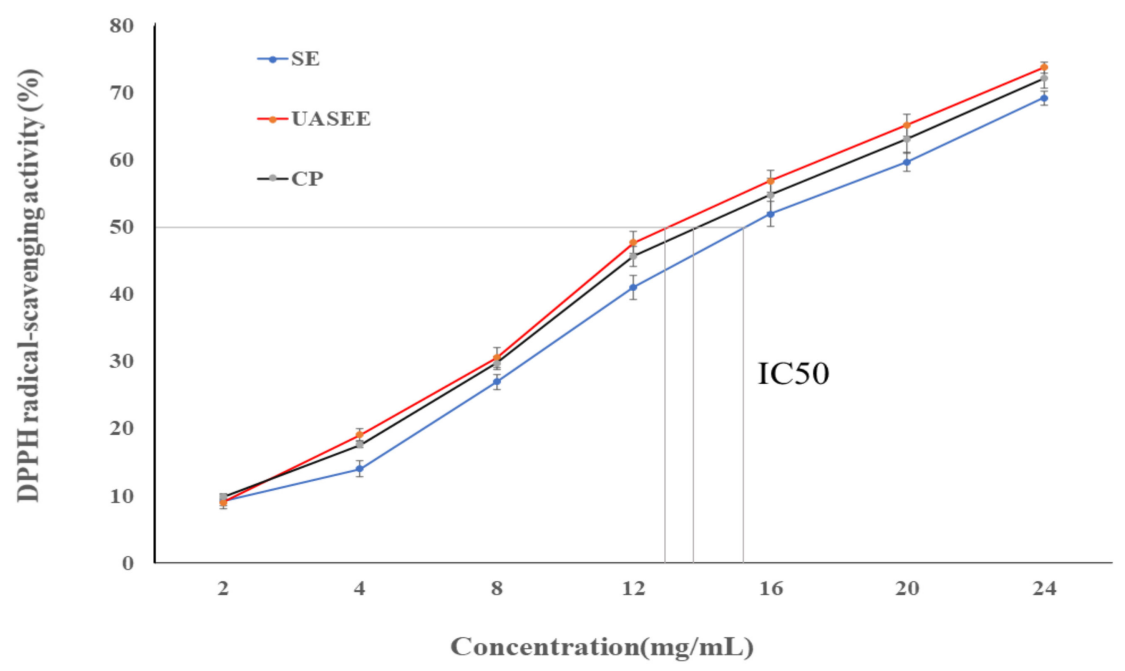

Figure 3. Antioxidant activity of E.mollis oil obtained by different methods.

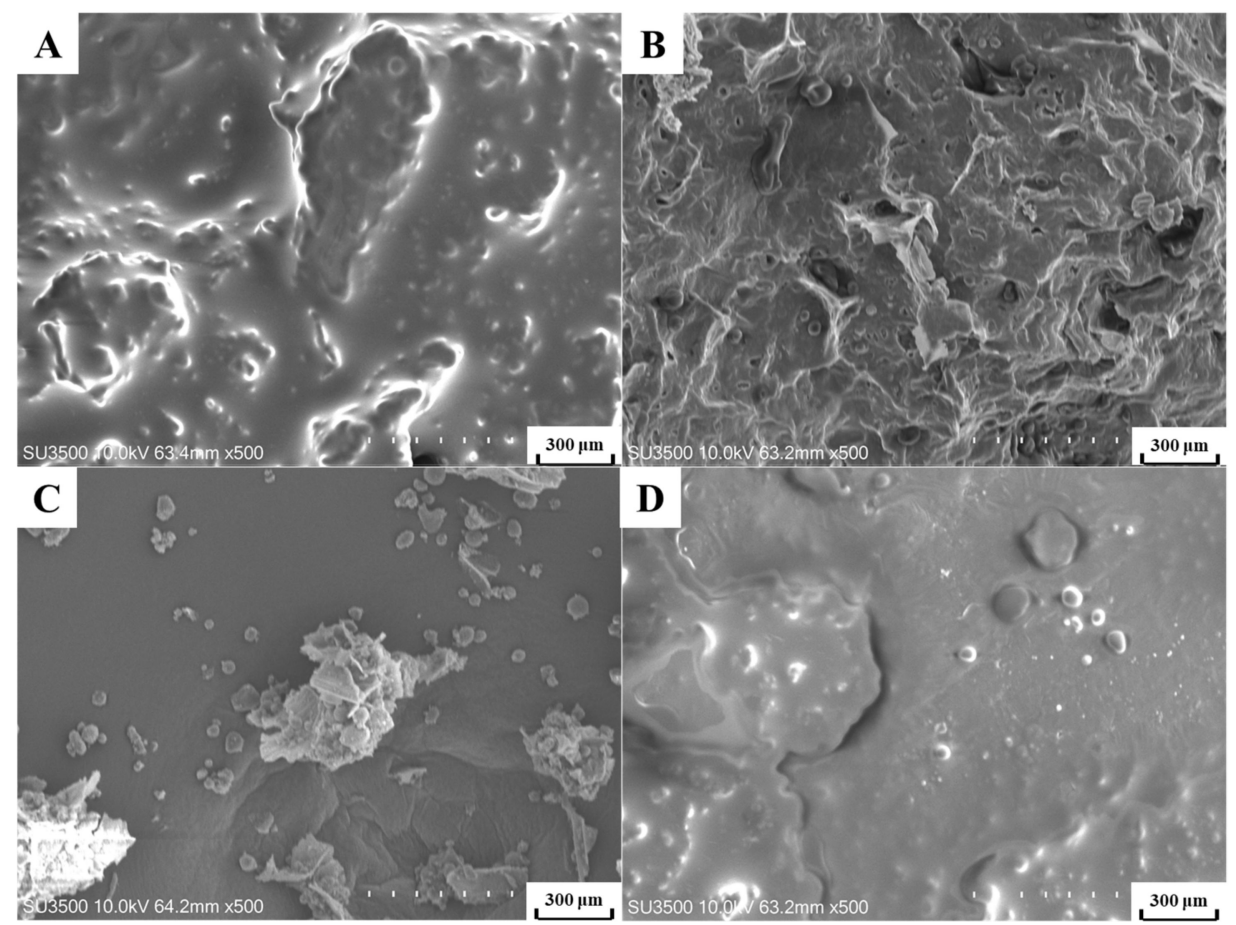

Figure 4. Scanning electron microscopy images of E. mollis powder: (A) Untreated, (B) UASEE residue, $(\mathbf{C})$ SE residue, $(\mathbf{D}) \mathrm{CP}$ residue.

\subsection{Thermal Stability}

Thermogravimetric analysis (TGA) and its corresponding derivative thermogravimetric analysis (DTG) can be used to analyze the thermal stability of E. mollis oil. Based on the TGA and DTG results, the thermal degradation of E. mollis oil was divided into two stages. The first degradation stage occurred at $152-251^{\circ} \mathrm{C}$, and was due to the decomposition of polyunsaturated fatty acids [51]. The second degradation stage occurred at $251-422{ }^{\circ} \mathrm{C}$, 
and was the major weight loss stage. It could be attributed to changes in the chain length, degree of unsaturation, and branching of fatty acids [51,52]. Additionally, the DTGMAx for the oils treated by UASEE, SE, and CP was observed at $375.26{ }^{\circ} \mathrm{C}, 381.32{ }^{\circ} \mathrm{C}$, and $353.00{ }^{\circ} \mathrm{C}$, respectively, while the respective weight loss of the oils was $50.21 \%, 54.60 \%$, and $50.29 \%$ in this stage. The oil obtained by UASEE exhibited the lowest weight loss compared to CP oil and SE oil, suggesting its better thermal stability. As can be vividly seen in Figure 5, the degradation of E. mollis oil began at $152{ }^{\circ} \mathrm{C}$; it can be assumed that the E. mollis oil would be thermally stable in industrial production with processing temperatures lower than $150{ }^{\circ} \mathrm{C}$.
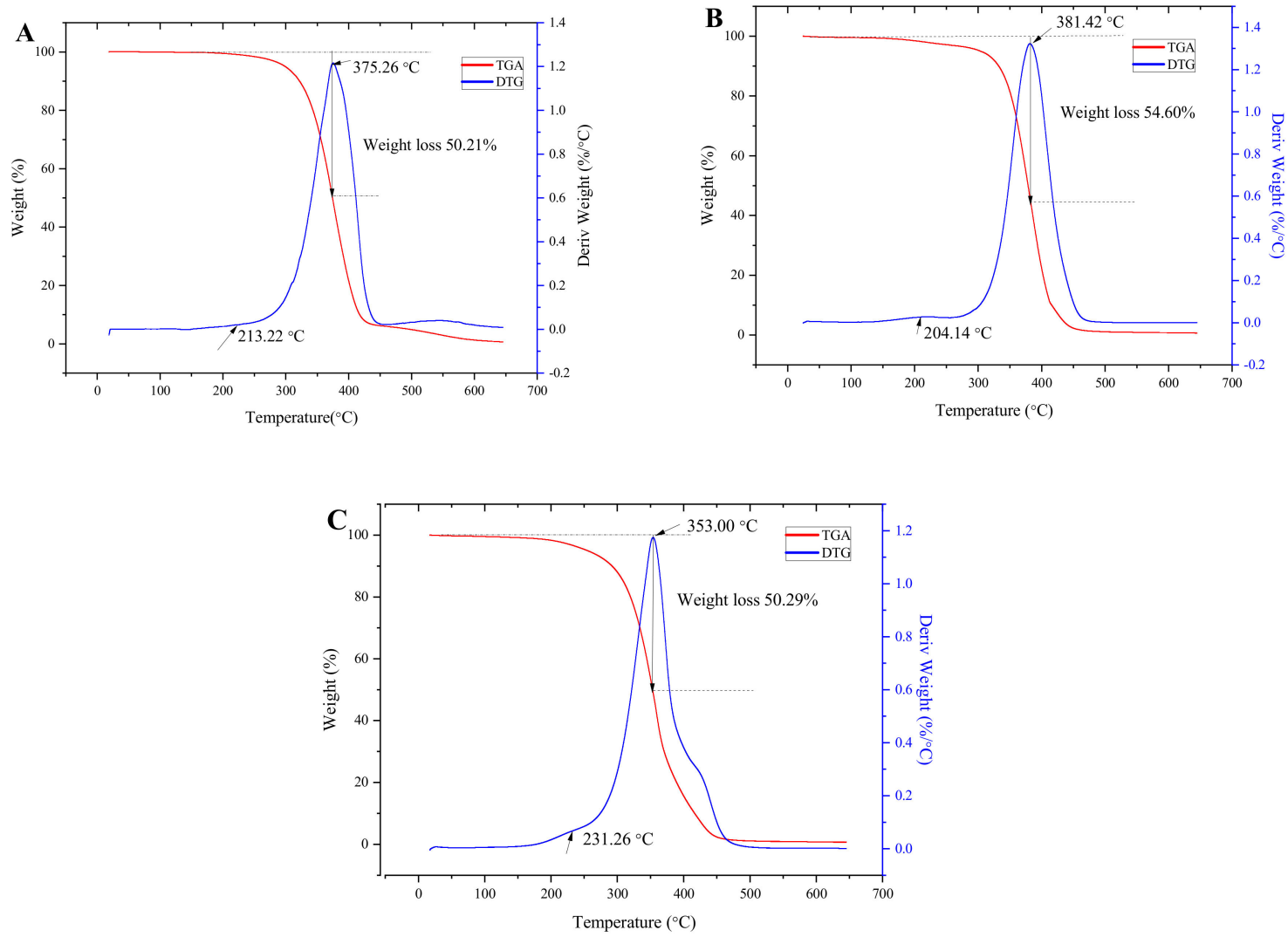

Figure 5. TGA and DTG curves of E. mollis oil obtained after three different processes: (A) UASEE, (B) SE, (C) CP.

\section{Conclusions}

In this study, we compared the effects of UASEE and conventional processing methods (SE and CP) on the fatty acid content profiles, physicochemical properties, bioactive compounds, antioxidant activity, and thermal behavior of E. mollis oil.

All the results illustrate that UASEE has an important effect on oil quality. The UASEE oil exhibited more advantages in functionality, including more unsaturated fatty acids, tocopherols and tocotrienols, squalene, phytosterols, and phenolic contents. The oil obtained by UASEE showed a relatively lower weight loss than the other two oils, suggesting its better thermal stability. Scanning electron microscopy showed damage to the cell walls and release of substances from cells with UASEE. Thus, through evaluation of its physicochemical properties, functional compounds, antioxidant activity, and thermal stability, the E. mollis oil obtained with the UASEE process has potential for application as a natural antioxidant or functional regredient applied in the future food process industry, thanks to its excellent DPPH radical scavenging activity and the advantages of abundant unsaturated fatty acids and bioactive compounds. The present study provides ideas for the further development of $E$. mollis oil-related functional foods. 
Supplementary Materials: The following are available online at https:/ /www.mdpi.com/article/ 10.3390/foods11030359/s1, Figure S1: Chromatograms of tocopherols and tocotrienols standard solution. Figure S2: Chroma-tograms of tocopherols and tocotrienols sample solution of UASEE oil. Figure S3: Quantitative ion chromatograms of squalene standard solution. Figure S4: Quantitative ion chromatograms of squalene sample solution of UASEE oil. Figure S5: Total ion chromatograms (TIC) of phytosterols standard solution. Figure S6: Quantitative ion chromatograms of phytosterols standard solution. Figure S7: Quantitative ion chromatograms of phytosterols sample solution of UASEE oil. Figure S8: Total ion chromatograms (TIC) of phenolic compounds standard solution. Figure S9: Quanti-tative ion chromatograms of phenolic compounds standard solution. Figure S10: Quantitative ion chromatograms of phenolic compounds sample solution of UASEE oil.

Author Contributions: Conceptualization, X.L.; methodology, X.L.; investigation, X.L. and H.D.; data curation, X.L., H.D. and Y.L.; writing-original draft preparation, X.L.; writing-review and editing, Y.W.; supervision, D.L. and L.W.; funding acquisition, D.L and L.W. All authors have read and agreed to the published version of the manuscript.

Funding: This research was supported by the National Key Research and Development Program of China (Grant number: 2021YFD2101000).

Data Availability Statement: Data available on request from the authors.

Conflicts of Interest: The authors declare no conflict of interest.

\section{References}

1. Zhou, Y.; Zhao, W.; Lai, Y.; Zhang, B.; Zhang, D. Edible Plant Oil: Global Status, Health Issues, and Perspectives. Front. Plant Sci. 2020, 11, 1315. [CrossRef] [PubMed]

2. Ceole, L.F.; Cardoso, M.D.G.; Soares, M.J. Nerolidol, the main constituent of Piper aduncum essential oil, has anti-Leishmania braziliensis activity. Parasitology 2017, 144, 1179-1190. [CrossRef] [PubMed]

3. Jassbi, A.R.; Zare, M.; Jamebozorgi, F.H. Chemical Composition and Biological Activity of the Essential Oil and Solvent Extracts of Scaligeria Nodosa. Open Bioact. Compd. J. 2017, 5, 16-22. [CrossRef]

4. Limaverde, P.W.; Campina, F.E.; da Cunha, F.A.B.; Crispim, F.D.; Figueredo, F.G.; Lima, L.F.; Tintino, C.; de Matos, Y.; MoraisBraga, M.F.B.; Menezes, I.R.A.; et al. Inhibition of the TetK efflux-pump by the essential oil of Chenopodium ambrosioides L. and alpha-terpinene against Staphylococcus aureus IS-58. Food Chem. Toxicol. 2017, 109, 957-961. [CrossRef]

5. Carneiro, N.S.; Alves, C.C.F.; Alves, J.M.; Egea, M.B.; Martins, C.H.G.; Silva, T.S.; Bretanha, L.C.; Balleste, M.P.; Micke, G.A.; Silveira, E.V.; et al. Chemical composition, antioxidant and antibacterial activities of essential oils from leaves and flowers of Eugenia klotzschiana Berg (Myrtaceae). An. Acad. Bras. Cienc. 2017, 89, 1907-1915. [CrossRef]

6. Ghasemi, Y.Z.; Dinani, S.T. Optimization of ultrasound-assisted enzymatic extraction of walnut kernel oil using response surface methodology. J. Food Process. Eng. 2018, 41, 18. [CrossRef]

7. Yuan, W.Q.; Hu, J.Z.; Yin, L.Q.; Lv, Z.L. Comparative Analysis of Essential Bioactive Components of Oils Originating from Three Chinese Loess Plateau Wild Crops. J. Am. Oil Chem. Soc. 2021, 98, 531-540. [CrossRef]

8. Wang, C.X.; Duan, Z.H.; Fan, L.P.; Li, J.W. Supercritical $\mathrm{CO}_{2}$ Fluid Extraction of Elaeagnus mollis Diels Seed Oil and Its Antioxidant Ability. Molecules 2019, 24, 911. [CrossRef]

9. Chen, Y. Effects of Elaeagnus mollis Diels. seed oil on antioxidant capacity and lipid metabolism of mice. China Oils Fats 2017, 42, 77-80.

10. Wang, X.M.; Bai, B.; Li, J.; Zhang, K.; Xie, Y.; Xun, B.N.; Bi, X.P. Development of the Elaeagnus Mollis Oil Submicron-emulsion of Its Anti-fatigue Activity. Food Res. Dev. 2018, 39, 159-165.

11. Guo, C.X.; Qiao, J.P.; Zhang, S.W.; Li, M.P.; Li, J.; Hatab, S. Elaeagnus mollis Oil Attenuates Non-Alcoholic Fatty Disease in High-Fat Diet Induced Obese Mice via Modifying the Expression of Lipid Metabolism-Related Genes. J. Oleo Sci. 2019, 68, 893-908. [CrossRef]

12. Lee, K.Y.; Rahman, M.S.; Kim, A.N.; Jeong, E.J.; Kim, B.G.; Lee, M.H.; Kim, H.J.; Choi, S.G. Effect of superheated steam treatment on yield, physicochemical properties and volatile profiles of perilla seed oil. LWT-Food Sci. Technol. 2021, 135, 8. [CrossRef]

13. Martinez, M.L.; Mattea, M.A.; Maestri, D.M. Pressing and supercritical carbon dioxide extraction of walnut oil. J. Food Eng. 2008, 88, 399-404. [CrossRef]

14. Singla, M.; Sit, N. Application of ultrasound in combination with other technologies in food processing: A review. Ultrason. Sonochem. 2021, 73, 105506. [CrossRef]

15. Heidari, S.H.; Dinani, S.T. The Study of Ultrasound-Assisted Enzymatic Extraction of Oil From Peanut Seeds Using Response Surface Methodology. Eur. J. Lipid Sci. Technol. 2018, 120, 13. [CrossRef]

16. Amigh, S.; Dinani, S.T. Combination of ultrasound-assisted aqueous enzymatic extraction and cooking pretreatment for date seed oil recovery. Heat Mass Transf. 2020, 56, 2345-2354. [CrossRef]

17. Kan, L.N.; Wang, L.; Ding, Q.Z.; Wu, Y.W.; Ouyang, J. Flash Extraction and Physicochemical Characterization of Oil from Elaeagnus mollis Diels Seeds. J. Oleo Sci. 2017, 66, 345-352. [CrossRef] 
18. Lu, X.R.; Wu, D.; Wang, Y.; Li, D.; Wang, L.J. Evaluation of yield and quality properties of Elaeagnus mollis oil produced by ultrasound-assisted solvent enzymatic extraction. Int. J. Food Eng. 2021, in press. [CrossRef]

19. AOAC. Official Methods of Analysis, 18th ed.; Association of Official Analytical Chemists: Washington, DC, USA, 2005.

20. Naik, M.; Natarajan, V.; Rawson, A.; Rangarajan, J.; Manickam, L. Extraction kinetics and quality evaluation of oil extracted from bitter gourd (Momardica charantia L.) seeds using emergent technologies. LWT-Food Sci. Technol. 2021, 140, 110714. [CrossRef]

21. Ben Mohamed, H.; Duba, K.S.; Fiori, L.; Abdelgawed, H.; Tlili, I.; Tounekti, T.; Zrig, A. Bioactive compounds and antioxidant activities of different grape (Vitis vinifera L.) seed oils extracted by supercritical $\mathrm{CO}_{2}$ and organic solvent. LWT-Food Sci. Technol. 2016, 74, 557-562. [CrossRef]

22. Ministry of Agriculture and Rural Affairs of the People's Republic of China. Determination of Squalene in Vegetable Oil; NY/T 3673-2020; Ministry of Agriculture and Rural Affairs of the People's Republic of China: Beijing, China, 2020; pp. 1-40.

23. State Administration for Market Regulation of China. Determination of Sterols; GB/T 39995-2021; State Administration for Market Regulation of China: Beijing, China, 2021; pp. 1-40.

24. Ribeiro, P.P.C.; Damasceno, K.; de Veras, B.O.; de Oliveira, J.R.S.; Lima, V.L.D.; de Assis, C.R.D.; da Silva, M.V.; de Sousa, F.C.; de Assis, C.F.; Padilha, C.E.D.; et al. Chemical and biological activities of faveleira (Cnidoscolus quercifolius Pohl) seed oil for potential health applications. Food Chem. 2021, 337, 127771. [CrossRef]

25. Liu, Y.Y.; Sun, W.H.; Li, B.Z.; Shang, N.; Wang, Y.; Lv, W.Q.; Li, D.; Wang, L.J. Value-added application of Platycodon grandiflorus (Jacq.) A.DC. roots (PGR) by ultrasound-assisted extraction (UAE) process to improve physicochemical quality, structural characteristics and functional properties. Food Chem. 2021, 363, 130354. [CrossRef]

26. Silva, E.K.; Azevedo, V.M.; Cunha, R.L.; Hubinger, M.D.; Meireles, M.A.A. Ultrasound-assisted encapsulation of annatto seed oil: Whey protein isolate versus modified starch. Food Hydrocoll. 2016, 56, 71-83. [CrossRef]

27. Gharsallah, K.; Rezig, L.; Msaada, K.; Chalh, A.; Soltani, T. Chemical composition and profile characterization of Moringa oleifera seed oil. S. Afr. J. Bot. 2021, 137, 475-482. [CrossRef]

28. Li, T.; Qu, X.Y.; Zhang, Q.A.; Wang, Z.Z. Ultrasound-assisted extraction and profile characteristics of seed oil from Isatis indigotica Fort. Ind. Crop. Prod. 2012, 35, 98-104. [CrossRef]

29. Xu, D.X.; Hao, J.; Wang, Z.H.; Liang, D.D.; Wang, J.H.; Ma, Y.S.; Zhang, M. Physicochemical properties, fatty acid compositions, bioactive compounds, antioxidant activity and thermal behavior of rice bran oil obtained with aqueous enzymatic extraction LWT-Food Sci. Technol. 2021, 149, 111817. [CrossRef]

30. Zhang, L.; Zhou, C.S.; Wang, B.; Yagoub, A.A.; Ma, H.L.; Zhang, X.; Wu, M. Study of ultrasonic cavitation during extraction of the peanut oil at varying frequencies. Ultrason. Sonochem. 2017, 37, 106-113. [CrossRef]

31. Fu, M.; Qu, Q.; Yang, X.; Zhang, X. Effect of intermittent oven drying on lipid oxidation, fatty acids composition and antioxidant activities of walnut. LWT-Food Sci. Technol. 2016, 65, 1126-1132. [CrossRef]

32. Ma, W.J.; Qi, B.K.; Li, Y.; Wang, J.; Feng, H.X.; Cao, L.; Sui, X.N.; Jiang, L.Z. Aqueous Enzymatic Extraction Assisted by Ultrasonic of Oil from Evening Primrose Seed. Food Nutr. China 2015, 21, 54-58.

33. Jiao, J.; Li, Z.G.; Gai, Q.Y.; Li, X.J.; Wei, F.Y.; Fu, Y.J.; Ma, W. Microwave-assisted aqueous enzymatic extraction of oil from pumpkin seeds and evaluation of its physicochemical properties, fatty acid compositions and antioxidant activities. Food Chem. 2014, 147, 17-24 [CrossRef] [PubMed]

34. Chen, F.L.; Zhang, Q.; Fei, S.M.; Gu, H.Y.; Yang, L. Optimization of ultrasonic circulating extraction of samara oil from Acer saccharum using combination of Plackett-Burman design and Box-Behnken design. Ultrason. Sonochem. 2017, 35, 161-175. [CrossRef] [PubMed]

35. Liu, Z.Z.; Gui, M.L.; Xu, T.T.; Zhang, L.; Kong, L.T.; Qin, L.; Zou, Z.R. Efficient aqueous enzymatic-ultrasonication extraction of oil from Sapindus mukorossi seed kernels. Ind. Crops Prod. 2019, 134, 124-133. [CrossRef]

36. Hu, B.; Xi, X.H.; Li, H.C.; Qin, Y.X.; Li, C.; Zhang, Z.Q.; Liu, Y.T.; Zhang, Q.; Liu, A.P.; Liu, S.X.; et al. A comparison of extraction yield, quality and thermal properties from Sapindus mukorossi seed oil between microwave assisted extraction and Soxhlet extraction. Ind. Crops Prod. 2021, 161, 12. [CrossRef]

37. Liang, S.H.; Yang, R.N.; Dong, C.W.; Yang, Q.P. Physicochemical Properties and Fatty Acid Profiles of Elaeagnus mollis Diels Nut Oils. J. Oleo Sci. 2015, 64, 1267-1272. [CrossRef]

38. Chiacchierini, E.; Mele, G.; Restuccia, D.; Vinci, G. Impact evaluation of innovative and sustainable extraction technologies on olive oil quality. Trends Food Sci. Technol. 2007, 18, 299-305. [CrossRef]

39. Nyam, K.L.; Tan, C.P.; Lai, O.M.; Long, K.; Man, Y.B.C. Physicochemical properties and bioactive compounds of selected seed oils. LWT-Food Sci. Technol. 2009, 42, 1396-1403. [CrossRef]

40. Mathur, P.; Ding, Z.F.; Saldeen, T.; Mehta, J.L. Tocopherols in the Prevention and Treatment of Atherosclerosis and Related Cardiovascular Disease. Clin. Cardiol. 2015, 38, 570-576. [CrossRef]

41. Konopka, I.; Roszkowska, B.; Czaplicki, S.; Tanska, M. Optimization of Pumpkin Oil Recovery by Using Aqueous Enzymatic Extraction and Comparison of the Quality of the Obtained Oil with the Quality of Cold-Pressed Oil. Food Technol. Biotechnol. 2016, 54, 413-420. [CrossRef]

42. Fang, X.Z.; Du, M.H.; Luo, F.; Jin, Y.F. Physicochemical Properties and Lipid Composition of Camellia Seed Oil (Camellia oleifera Abel.) Extracted Using Different Methods. Food Sci. Technol. Res. 2015, 21, 779-785. [CrossRef] 
43. Ferrentino, G.; Giampiccolo, S.; Morozova, K.; Haman, N.; Spilimbergo, S.; Scampicchio, M. Supercritical fluid extraction of oils from apple seeds: Process optimization, chemical characterization and comparison with a conventional solvent extraction. Innov. Food Sci. Emerg. Technol. 2020, 64, 102428. [CrossRef]

44. Basyigit, B.; Daghan, S.; Karaaslan, M. Biochemical, compositional, and spectral analyses of Isot (Urfa pepper) seed oil and evaluation of its functional characteristics. Grasas Y Aceites 2020, 71, 384. [CrossRef]

45. Tripoli, E.; Giammanco, M.; Tabacchi, G.; Di Majo, D.; Giammanco, S.; La Guardia, M. The phenolic compounds of olive oil: Structure, biological activity and beneficial effects on human health. Nutr. Res. Rev. 2005, 18, 98-112. [CrossRef]

46. Han, C.P.; Liu, Q.G.; Jing, Y.Q.; Wang, D.; Zhao, Y.; Zhang, H.; Jiang, L.Z. Ultrasound-Assisted Aqueous Enzymatic Extraction of Corn Germ Oil: Analysis of Quality and Antioxidant Activity. J. Oleo Sci. 2018, 67, 745-754. [CrossRef]

47. Chen, R.Z.; Liu, Z.Q.; Zhao, J.M.; Chen, R.P.; Meng, F.L.; Zhang, M.; Ge, W.C. Antioxidant and immunobiological activity of water-soluble polysaccharide fractions purified from Acanthopanax senticosu. Food Chem. 2011, 127, 434-440. [CrossRef]

48. Rosenthal, A.; Pyle, D.L.; Niranjan, K. Aqueous and enzymatic processes for edible oil extraction. Enzym. Microb. Technol. 1996, 19, 402-420. [CrossRef]

49. Zhang, Z.S.; Wang, L.J.; Li, D.; Jiao, S.S.; Chen, X.D.; Mao, Z.H. Ultrasound-assisted extraction of oil from flaxseed. Sep. Purif. Technol. 2008, 62, 192-198. [CrossRef]

50. Jadhav, A.J.; Holkar, C.R.; Goswami, A.D.; Pandit, A.B.; Pinjari, D.V. Acoustic Cavitation as a Novel Approach for Extraction of Oil from Waste Date Seeds. ACS Sustain. Chem. Eng. 2016, 4, 4256-4263. [CrossRef]

51. Santos, J.C.O.; dos Santos, I.M.G.; de Souza, A.G.; Prasad, S.; dos Santos, A.V. Thermal stability and kinetic study on thermal decomposition of commercial edible oils by thermogravimetry. J. Food Sci. 2002, 67, 1393-1398. [CrossRef]

52. Borugadda, V.B.; Goud, V.V. Thermal, oxidative and low temperature properties of methyl esters prepared from oils of different fatty acids composition: A comparative study. Thermochim. Acta 2014, 577, 33-40. [CrossRef] 